\title{
QUANTITATIVE ANALYSIS OF ACTIVATED T LYMPHOCYTES \\ BY VIRUS PLAQUE ASSAY IN PATIENTS WITH HEAD AND NECK CANCER
}

\author{
HIROSHI TAKENAKA, M. D., AKINORI HOSHINO, M. D., \\ SHIGERU MIYOSHI, M. D. HIDEKI KIDA, M. D. \\ HITOSHI SAITO, M. D. OSAMU MIZUKOSHI, M. D. \\ Department of Otorhinolaryngology Kyoto Prefectural University of Medicine \\ (Director: O. Mizukoshi, M. D.) \\ TAKASHI AMAGAI, Ph. D. \\ Department of Microbiology Kyoto Prefectual University of Medicine \\ (Director: T. Kishsda, M. D.)
}

\begin{abstract}
Most of the investigations about immune potential of peripheral blood lymphocytes in cancer patients up to now have been studied with non-specific or tumor specific qualitative mitotic responses in vitro. In order to study immunological responsiveness quantitatively, virus plaque assay devised by B. R. Bloom was applied to determine immune potentials of the patients with head and neck cancer and the normal subjects. It has been reported that by this method the number of activated lymphocytes with a mitogen or antigen could be enumerated. Using this method, the number of Concanavalin A (Con A)-activated lymphocytes in cancer patients was examined. The cancer patient consisted of non-Hodgkin malignant lymphoma (7 cases), lingual cancer ( 6 cases), laryngeal cancer ( 5 cases), and miscellaneous ( 6 cases).

The number of virus plaque forming cells (VPFC) activated by Con A was subtracted from that of VPFC without Con A. The subtracted number ( $\triangle \mathrm{VPFC}$ ) in the cancer patients $(-1538 \pm 3197$, mean $\pm \mathrm{SD})$ was significantly smaller than that of 11 normal cases $(9727 \pm$ 9009) and 7 cases of benign diseases $(12537 \pm 23228)$. The number of $A V P F C$ in the cancer group was generally small regardless to the difference of the primary region of cancer, TNM classification, clinical stage, and the pathological findings. There was no correlation between the number of VPFC and that of peripheral blood lymphocytes in the cancer patients.

The advantages of virus plaque assay for immunological investigation in cancer patients were emphasized.
\end{abstract}




\title{
Virus Plaque Assay による頭頸部覀性腫煌患者の 活性化 Tリンパ球の定量的観察
}

\author{
京解府立医科大学耳鼻咽喉科学教室（主任：水越 治教授) \\ 竹中洋, 賈田唀澍, 三好茂, 星野伹筑, \\ 斎 藤 等, 水 㦲 治
}

京都府立医科大学微生物学教室(主任: 岸田䣋太郎教授)

雨具孝

\section{I 緒 言}

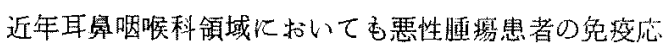

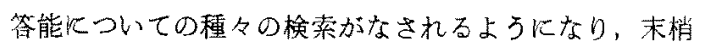
血リンバ球のT細胞比率の但下年2/3)，PPD，PHA 皮内 反応陽性率の低下 下) $32^{2}$ PHA, Con A K対する Mitogen response の低下などの報告がある。一方，頭頸部悪性 腫瘍は他科領域に比し次述べるらな特街吕ある。

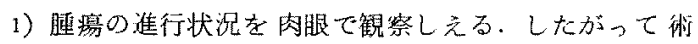
後の観祭も容易であり，再発，完治の見植めが容易であ る、2）抗癌剂，免疫賦活剂を多㻎汇使用しなくても外 科的処置のみで十分根治が期待できる症例もある。これ らの特徽は担㾇生体の免疫能の検討という点ても有利て あると考党る。

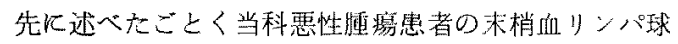
免疫応答能の解析は主として T B 細胞率の同定㭘督, リンパ球機能の面では皮内反心など定性的な方法でなさ れていて．今回，われ加れは Bloom 比り開発された， 活性化 T細胞内ではウィルスが增殖しえることを利用し たウィルスプラーク法 (Virus Plaque Assay以下VPA 法之略す）を，恶性腫演患者の兔度応答能検査儿用い， 活性化 T細胞の定量化交試みた。

\section{II 実 験 方 法}

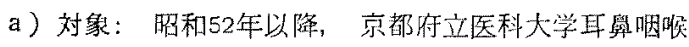
科を受略した㭧者のうち，1）頭钼部悪性腫疼と確定診 断されたもの 24 例，2）副舅腔资を始めとする良性疾息 々者 7 例, 对照として 3) 正常成人供血者 11 例老使用 した。店拓, 悪性腫瘍群は原則之して確定診断娞未治游 のものとし，ステロイド削投与などはおこなっていな い. 以上の3群について下記灶述べる力法にしたがって
奏験を拈こなった（症例内訳けは表 $1 ， 2$ 参照）。

b）方法：以下の 2 万法上りなる。

$b-1)$ ：末梢血リンパ球の培琵

ヘパリン加束梢静脈血 $20 \mathrm{~m} l$ に同聂のリン酸塩類等张 波（以下 PBS(一) 上略す）Kて上く淈和し Ficoll Hypaque sedimentation でリンパ球を分離, Eagle Minimum Essential Medium (以下 E-MEM と略す)

\section{表 1}

Classification of Malignant Tumors

$\begin{array}{ll}\text { Malignant Lymphoma } & 7 \\ \text { Carcinoma of the Oral Tongue } & 6 \\ \text { Carcinona of the Laryox } & 5 \\ \text { Carcinoma of the Sinuses } & 1 \\ \text { Carcinoma of the Alveoli } & 1 \\ \text { Carcinoma of the Thyroid Gland } & 1 \\ \text { Carcinoma of the Parotid Gland } & 1 \\ \text { Caxcinoma of the Nose } & 1 \\ \text { Carcinoma of the Tonsil } & 1 \\ \end{array}$

表 2

\begin{tabular}{|c|c|}
\hline \multicolumn{2}{|c|}{$\begin{array}{l}\text { Classification of } \\
\text { other Discases }\end{array}$} \\
\hline Otitis chr & 3 \\
\hline Sinusitis chr & 2 \\
\hline Mixed Tunior & I \\
\hline $\begin{array}{l}\text { relapsing } \\
\text { polychondritis }\end{array}$ & 1 \\
\hline $\operatorname{cotal}$ & 7 \\
\hline
\end{tabular}


にて浮遊遠沈をくり返して洗浄，10\%牛胎览血清加 RPMI 1640培地飞浮遊させ, 細胞数を $1 \times 10^{8} / \mathrm{ml}$ K調 整し, この $1 \mathrm{~m} l k$ Concanvalin A (以下 Con A と略 す) $5 \mu \mathrm{g}$ (または $2.5 \mu \mathrm{g}$ ) を加えた Con A 添加群と対 照として非添加群をつくり，プラスチックチューブにて

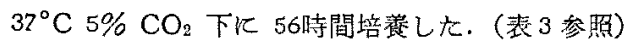

\section{表 3}

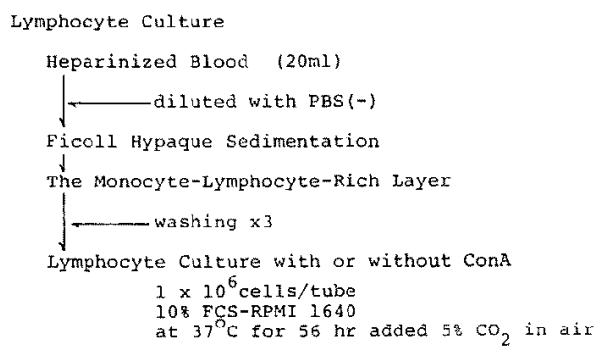

b-2): VPA 法

Bloom の方法に準じ培罴後回収したリンパ球を1回 遠沈し，E-MEM 飞浮遊さ妙生細胞数を測定した. $5 \%$ 牛胎児血清加 E-MEM Kて $0.2 \mathrm{~m} l$ V調整しVesicular Stomatitis Virus. New Jersey 株 (以下 VSV と格す) を 20 multiplicity of infection 加え，上く混和した後， $37^{\circ} \mathrm{C} 5 \% \mathrm{CO}_{2}$ 下に 2 時間门ィルスを吸着させた。ウ1 ルス吸着後，浮遊遠沈をくり返してリンパ球を洗浄し， さらに抗VSV 血清 $(0.05 \mathrm{~m} l /$ tube $)$ 处理在 $4^{\circ} \mathrm{C}$ にて1 時間行い，遊離 virus を中和した。この後 2 回E-MEM にて洗净し，E-MEMK再浮遊させた生細胞数を測定し た、ウィルス在吸着させたリンパ球はあらかじめ用意し

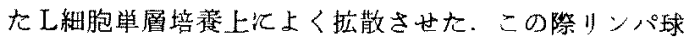

\section{表 4}

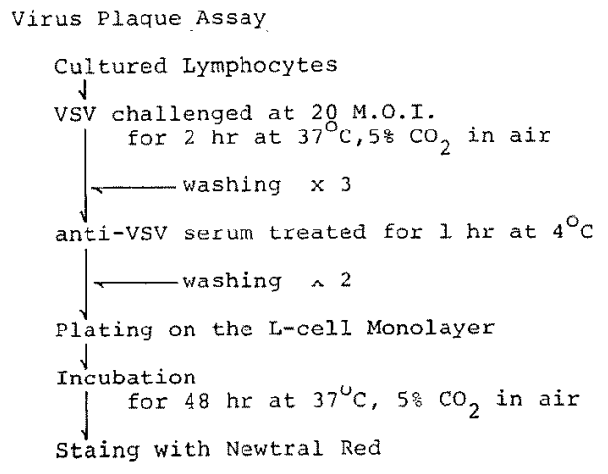

は2 段陆苻彩液に調整し，各希釈液 2 枚宛。L絓胞単層

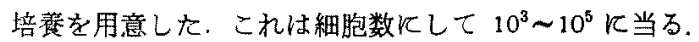
次いで 5\%牛胎見血清，1\%寒天加 E-MEM 省電層し た.これを $37^{\circ} \mathrm{C}, 5 \% \mathrm{CO}_{2}$ 下にて 2 日間培盎し中性赤で 染色し，生じた Plaque 数を測定した (表 4 参照).

Plaque 数はまきこんだリンパ球数 $10^{6}$ 個 あたりに換 算し, 培衰液に Con A を加えた群に生した Plaque 数 より，非添加群に生じた Plaque 数を減じたものを UVPFC としこの数について比較検討した. 式で示すと 下記のごとくなる。

$\triangle \mathrm{VPFC}=\mathrm{Con} \mathrm{A}$ 添加群の VPFC一Con A 非添加群 の VPFC．また，各実験に際し，正常成人末梢静脈血り ンパ球を同様の方法で調く対照として使用した。

\section{III 粘果}

a）正常群，恶性腫助群，その他の疾患群の $\triangle \mathrm{VPFC}$ :

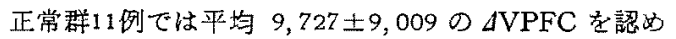

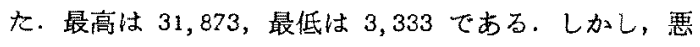
性腫湯群では最高 3,625 の

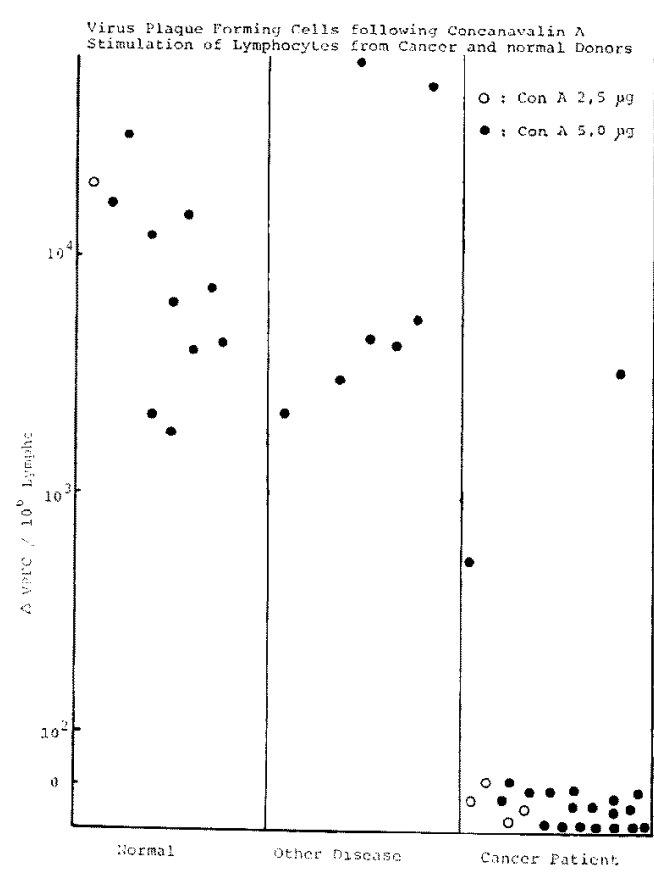

国 1

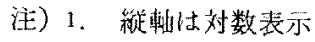

2. UVPFC が目を示したものは。以下に まとめて表示した。 
いては50以下であった，平均一1,538土3,197 のJVPFC を認めた，その他の疾㭧群 7 例では12,537 23,228 の平 均值を示したが，これは $\Delta \mathrm{VPFC}$ の值が2,116 65,000 となったためで，悪性埂瘍群仗みられた極端な低值を示 するのはなく，ほほ正常人に等しい結果を得た（図 1 参 照).

以下，喉頭澏，悪性リンバ腫，苦癌の症例別の湘定值 を示す。

a-1) 喉頭癌症は例表 5 亿示すごとく， $\mathrm{T}_{1} \mathrm{~N}_{0} \mathrm{M}_{0} 2$ 例,

\section{表 5}

Virus Flaque Formation by Laryngeal Cancer Lymphocytes wh or without con $A$

\begin{tabular}{|c|c|c|c|c|c|}
\hline \multirow{2}{*}{$\begin{array}{l}\text { Donor's } \\
\text { number }\end{array}$} & \multirow[t]{2}{*}{ TNM } & \multirow[t]{2}{*}{ Fathology } & \multicolumn{3}{|c|}{ PFC/10 $10^{5}$ ymphocytes $\triangle P F C / 10^{6}$} \\
\hline & & & absent & $\frac{\text { Con } A}{\text { present }}$ & 1 ymphocytes \\
\hline $11^{\circ}$ & $\mathrm{T}_{3} \mathrm{~N}_{0} 3 \mathrm{H}_{0}$ & $s, c, c$ & 255 & 300 & 45 \\
\hline 35 & $\mathrm{~T}_{4} \mathrm{~N}_{0} \mathrm{O}_{6}$ & & 10033 & 6060 & -4773 \\
\hline 39 & $a_{1 b} N_{0} M_{0}$ & & 0 & 0 & 0 \\
\hline 65 & $T_{4} N_{0} M_{0}$ & & 18750 & 10714 & -3036 \\
\hline 66 & $T_{2 a} \mathrm{~N}_{0} \mathrm{M}_{0}$ & & 0 & 0 & 0 \\
\hline
\end{tabular}

$\mathrm{T}_{3} \mathrm{~N}_{0} \mathrm{M}_{0} 1$ 例, $\mathrm{T}_{4} \mathrm{~N}_{0} \mathrm{M}_{0} 2$ 例であり，全例䎐移は認めて いな加った，病㻎組織所見は全て熶平上皮癌であった。 $\mathrm{a}-2)$ 悪性リンパ腫は stage 分類で IEA 4 例， II $\mathrm{IIA}_{E A} 1$

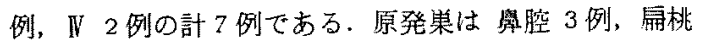
2 例, 耳下腺 1 例, 贸部リンパ節1例である. 全例 non Hodgikin malignant Lymphoma であった.なお, 聇 例 10 は採血前，原発果に $2000 \mathrm{rad}$ のコバルト照射を 施行していた，(表6参照)

a-3) 舌癌症例 6 例の弓ち，新鮮例は 4 例であり，これ

\section{表 6}

Virus Rlaque Fornation by Nalignant Lymphona Iymphocytes with or without con $A$

\begin{tabular}{|c|c|c|c|c|c|}
\hline $\begin{array}{l}\text { Donot's } \\
\text { number }\end{array}$ & origin & Stage & $\begin{array}{l}\mathrm{EFC/10} \\
\text { absent }\end{array}$ & $\frac{6^{6} \text { lymphocytes }}{\frac{\text { Con A }}{\text { present }}}$ & $\begin{array}{l}\triangle \mathrm{PFC} / 10^{6} \\
\text { lymphocytes }\end{array}$ \\
\hline $10^{\circ}$ & Neck & IV & 181 & 165 & -16 \\
\hline 46 & Ton:il & ${ }^{f} \mathrm{EFA}$ & 83 & 219 & -136 \\
\hline 47 & Nose & ${ }^{ \pm} E A$ & 1250 & 0 & -1250 \\
\hline 48 & Nose & IV & 400 & $\$ 27$ & 17 \\
\hline 64 & Nose & ${ }^{1} E A$ & 0 & 0 & 0 \\
\hline 103 & Tonsil & ${ }^{1} \mathrm{EA}$ & 2850 & 2450 & 0 \\
\hline 110 & Parotist & $I_{E A}$ & 2660 & 1520 & -1140 \\
\hline
\end{tabular}

らは全て転移を認めていない，症例13は舌半切術施行後 の再発例である。征例89 行，検查時ブレオマイシン $30 \mathrm{mg}$ 投与中であった，病理

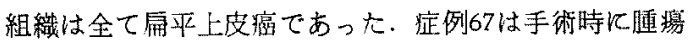
を全摘出した症例であるが，術中，抗癌剂，輸血を使用 世ず，街後一週目において VPFCを再検したとこる 4,642 と正常域回回復しており，予後判定の指摖として の有効泩も示唆された（表７参照）。

\section{表 7}

\begin{tabular}{|c|c|c|c|c|c|}
\hline \multirow{2}{*}{$\begin{array}{l}\text { Donor's } \\
\text { number }\end{array}$} & \multirow[t]{2}{*}{ Tะเมต } & \multirow[t]{2}{*}{ Pathology } & \multicolumn{2}{|c|}{$\frac{\mathrm{PFC} / 10^{6} \text { Iymphoeytes }}{\operatorname{con} \mathrm{A}}$} & \multirow{2}{*}{$\begin{array}{l}\text { DPFC/10 } \\
\text { lymphocytes }\end{array}$} \\
\hline & & & absent & present & \\
\hline $13^{\circ}$ & final & $s, c, c$, & $x y_{44}$ & 382 & -1563 \\
\hline 67 & $P_{1} N_{0} M_{0}$ & & 0 & 625 & 625 \\
\hline 71 & $T_{3} M_{0} M_{0}$ & & 1461 & 666 & -795 \\
\hline 43 & $\mathrm{~s}_{3} \mathrm{n}_{0} \mathrm{n}_{0}$ & & 3000 & 2500 & -500 \\
\hline 89 & therapy & & g) 25 & 1563 & -7562 \\
\hline 110 & $\mathrm{~T}_{2} \mathrm{~N}_{0} \mathrm{M}_{0}$ & & 2800 & 2600 & -200 \\
\hline
\end{tabular}

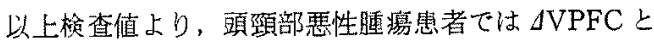

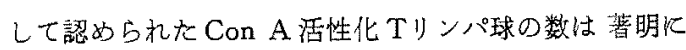
低值を示すことが明らかとなった，正常群では $J \mathrm{VPFC}$ として認められる活性化Tリンハ球の值が約 10,000 を 示したのに反して，悪性腫懪群では，予後が非常飞良好 と考元られる甲状腺腺癌症例か3 3,625 の值を示したのを 例外として $10^{2}$ 台以下であった.

b) 末梢血リンパ球数と Con A 活性化 Tリンパ球数の 相関:

絬果は図2に尓すごとくであった，横軸に末梢血りン

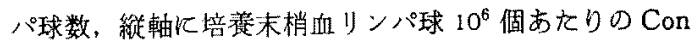
$\mathrm{A}$ 活性化 $\mathrm{T}$ リンパ球の值 VVPFC を图示した. 担癌個 体ではりンパ球数が十分ある例であ活性化 Tリンパ球数 が減少，末たは，代掘していることが判った。 その他の 䍩患群では，沫梢血リンパ球数は殆ど、正常域にあり， Con A 活性化 Tリンパ球数も宫值を示していることが 明らかである。

c) 担触患者の㛟查時の全身状態:

表 8 Kは末梢血中の白血球数，リンパ球数，赤血球数。 ヘマトクリット、へモグロビン鯂を記した，白血球数は 3例に10,000以上を認めたが Leukocytepenia Lymphocytepenia を示したものはなく, 平均值は各々6,547士 
Felationship betweensv-pFe and Lymphocytes

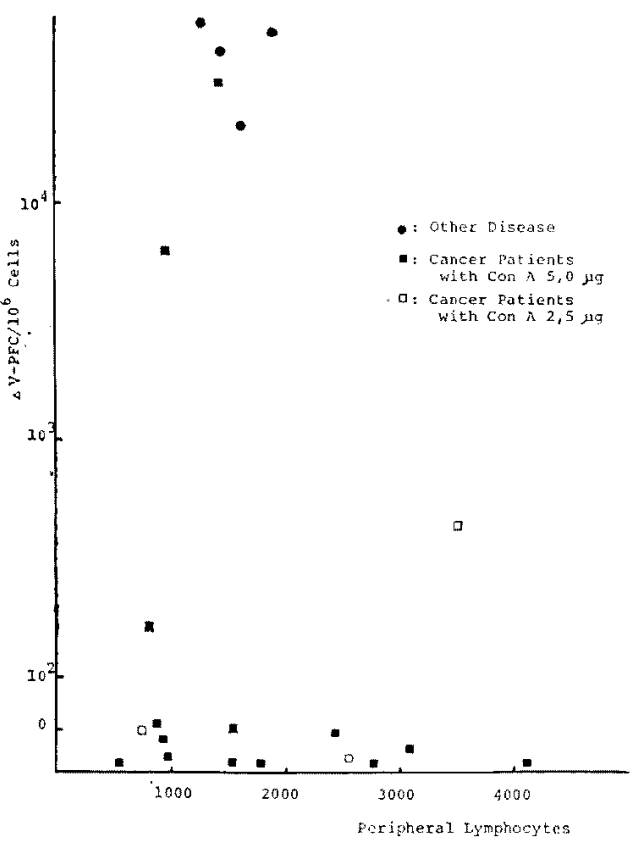

国 2

注）1。䋛軸は対数表示

2. $\Delta \mathrm{VPFC}$ が真の值を示す毛のは O以下 飞まとめた。

2,700(Mean $\pm \mathrm{SD}) ， 1,729 \pm 1,041$ (Mean士SD) と正常 域にあった, 亦航球数など, その他の㛟查值も正常域に あり，また自他筧的に重站合併柾は認めなかった，琵 9

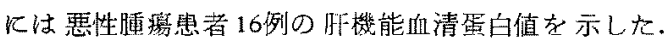

LDH，GOT，GPT は 全例正常值を示して招り，血清 蛋白も同様であった，以上より，全身状態は比較的正常 飞近く保れており，瑟液質を示したものもなく，検查時， 消耗性疾㭧による二次的な免疫能への影響は否定できる と考光る。

$$
\text { IV 若按 }
$$

われわれ臨床医が担癌急者の免疫動愁を知る大きな目 的は，「その観察法加患者の臨床経過，予後を反佒する か」ということにある、言葉を替えれば，兔疫動想を知 ることで，臨床経過が推測されれぱこれに越すものはな

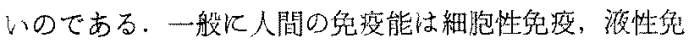
没，補体加らなっており，担癌生体の免疫能に関しては

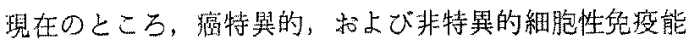

表 8

Blood Analysis of Doner's

\begin{tabular}{lrrrrrc}
$\begin{array}{l}\text { Donor's } \\
\text { number }\end{array}$ & WBC & Lymphocyte(8) & RBC & Itt & Hb \\
\hline 10 & 4300 & $774(18)$ & 443 & 45,3 & 15,6 \\
11 & 8900 & $3471(39)$ & 524 & 52,5 & 17,5 \\
13 & 10900 & $2616(24)$ & 361 & 35,6 & 10,9 \\
19 & 4300 & $903(21)$ & 421 & 43,2 & 14,0 \\
35 & 11300 & $2712(24)$ & 393 & - & 12,2 \\
38 & 6200, & $806(13)$ & 400 & 39,0 & 12,8 \\
39 & 8100 & $1620(20)$ & 485 & 45,5 & 15,3 \\
46 & 6000 & $960(16)$ & 430 & 44,5 & 15,2 \\
47 & 3700 & $555(15)$ & 478 & 47,4 & 15,7 \\
48 & 6800 & $680(10)$ & 347 & 34,8 & 11,5 \\
64 & & & & & & \\
65 & 11200 & $4144(37)$ & 490 & 47,4 & 17,0 \\
66 & 4900 & $2401(49)$ & 456 & 46,9 & 15,7 \\
67 & 3600 & $972(27)$ & 492 & 49,2 & 17,2 \\
71 & 8100 & $1863(23)$ & 467 & 44,7 & 16,4 \\
83 & 8500 & $3060(36)$ & 437 & 46,6 & 15,2 \\
88 & 4200 & $1302(31)$ & 495 & 42,6 & 14,0 \\
89 & 3700 & $1628(44)$ & 367 & 37,6 & 22,1 \\
\hline
\end{tabular}

$6547 \pm 2700 \quad 2729 \pm 1041 \quad 440 \pm 52 \quad 44 \leq 5 \quad 14,6 \pm 2,1$

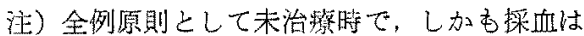
VPA の土3 日間とした。No.64は未治療 時の検查施行せず

表 9

Liver Function Test

\begin{tabular}{|c|c|c|c|c|c|c|c|}
\hline $\begin{array}{l}\text { Donor's } \\
\text { number }\end{array}$ & $\mathrm{LDH}$ & GOT & $\mathrm{GET}$ & $\begin{array}{l}\text { Plasma } \\
\text { Protein }\end{array}$ & $\mathrm{A} I$ & GI & $A / G$ \\
\hline 10 & 410 & 46 & 24 & 6,3 & 54,7 & 45,3 & 2,20 \\
\hline 11 & 280 & 23 & 20 & 7,0 & 53,6 & 46,4 & 1,15 \\
\hline 13 & - & 5 & 3 & 6,1 & 60,2 & 39,8 & 1,51 \\
\hline 29 & 180 & $10 \dot{0}$ & 4 & 6.2 & 60,6 & 39,4 & 1,53 \\
\hline 35 & 210 & 56 & 15 & 5.4 & 56,4 & 43,4 & 1,27 \\
\hline 39 & 310 & 16 & 15 & - & - & - & - \\
\hline 46 & 330 & 28 & 27 & 6,9 & 48,7 & 52,3 & 0,93 \\
\hline 47 & 360 & 27 & 7 & 7,4 & 57,0 & 43,0 & 1,32 \\
\hline 48 & 280 & 11 & 3 & 6,8 & 57,8 & 42,2 & 1,39 \\
\hline 65 & 400 & 30 & 27 & 8,2 & - & - & - \\
\hline 65 & 310 & 1.6 & 12 & $\rightarrow$ & - & - & - \\
\hline 67 & 460 & 23 & 17 & 8,1 & 56,5 & 43,5 & 1,30 \\
\hline $7 \mathrm{I}$ & 440 & 13 & 6 & 7,7 & $\in 1,0$ & 39,0 & 1,56 \\
\hline 83 & 450 & 20 & $y$ & 8,3 & 55,7 & 44,3 & 1,26 \\
\hline 8.8 & 370 & 27 & 6 & 8,3 & 58,9 & 41,1 & 1,43 \\
\hline 89 & - & 12 & 18 & - & $\leftarrow$ & - & - \\
\hline
\end{tabular}

注）全例原則として末治時療て，採血・検查は VPAの士3日間とした。 
表 10 癌患者の細胞性免疫能の測定く菞地〉

\begin{tabular}{|c|c|c|}
\hline & in vivo & in vitro \\
\hline 非 & 1. 末東梢りンパ球数 & 1. リンパ球好若化反応 (PHA, Con A, \\
\hline 特 & 2. 末梢 $\mathrm{T}$ 細胞数 (E-口ゼット，抗 $T$ ) & PWM) \\
\hline 異 & T細胞 subset 数 & 2. リンバ球混合培鉒 \\
\hline 的 & 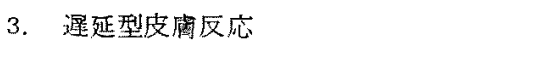 & 3. 同種細胞㜔㫪試䮖 \\
\hline & 一次区応：DNCB，KLH & 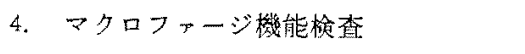 \\
\hline (一般的) & 二次反応 PPD, Candida, Mumps, & \\
\hline & 4. 同種細胞移植拒絶 & \\
\hline 癌 & 1. 兔疫組織学的检索* & 1. マクロファージ遊走阻止試験 (MIT) \\
\hline 特 & 2. 癌細胞と腎者リンパ球による中和試験 & 2. 白血球遊走阻上試㩔（LIT） \\
\hline 異 & 3. 癌細胞抗原による度革反応 & 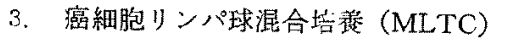 \\
\hline 的 & 4. 嵒細胞自家移植反肉 & 4. 変細胞障害武験 \\
\hline
\end{tabular}

*癌組織内丁細胞，マクロファージ浸潤，ただし非特買的反応像を含む

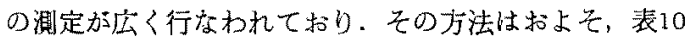
7)のこととく分類されている. in vitro の細胞性兔疫能に ついては Bloom”が述てているように，次の2点が必 要とされる.1) Effector cell が既知のリンパ球のSubpopulation と相関しているか，2）Effector cell の数の 定量, 反応の強さの定量ができるか，加えて invitroの

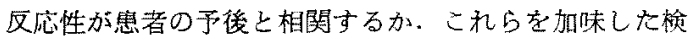
查法が望ま机る。

現行の免疫的梌香の多〈は幄延型皮馓反応，種々の Mitogenによるリンパ球纤若化の測定などである。これ らの方法ては，担癌状態と特に密接に関連していること が推測される細胞性兔瘵の担当細胞であるTリンパ球の 反応性の観察注定性的なるのとなっている。

われわれから回派告するVPA は Bloom によって delayed type hypersensitivity $\sigma$ effector cell tr in vitroに和いて定量的に観察するために考案されたの. Jimenez ${ }^{103}$ は続いてPPDの皮内反応とPPDを用いた VPFC 加相関関係にあることを報告し，PPD 皮内反応 陽性群比颃いて末梢血中の antigen sensitive cell 老定 量化するのに成功した，本法の基礎法，元来沫梢血のリ ソパ球内で休止期にウィルスが增殖することはないが， PHA, Con A などで活性化されたリンパ球のあるもの ではウィルスが增殖可能であるという事実によってい る、すなわち，予めCon A なと Mitogen Kよって活 性化されたリンパ球にウィルスを吸着させ，その細胞中 でのウィルス増殖の結果, リンハ球の崩解とウィルスの

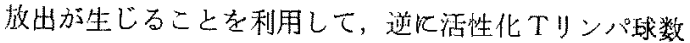
をプラークとして定量するということである。われわれ はConAを用いてTリンパ球を活性化し，VPFCを測定 した，本法沬他の in vitro の細胞性免疫能检查法之避 い活性化 Tリンパ球の定量化が可能であるということに その特徽がある(図 3 参照).

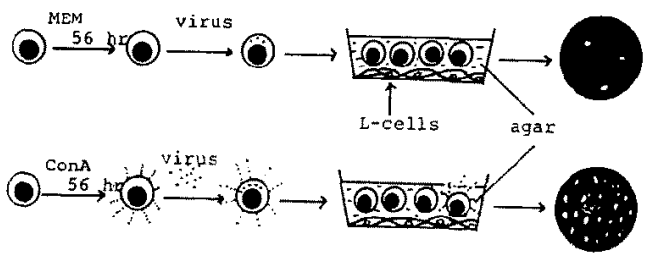

図 3

注）VPA の模式図，下は Con A で活性化さ れた活性化 Tリンバ球中での VSV の堌 殖を示す。上は非活性の Tリン八球と VSU の関係を示す

近年VPAを用いた研究は精力的に括こなわれている。 Bloom ${ }^{12)}$ がマウス脾稩胞を用いてVPFCが $\Upsilon$ リン人球 に属することを明らにしたのb，狩野ら ${ }^{13142}$ はマウス primary MLC で VPFC D発現肪 I regionの适い に反応する細胞群であることを示している。缺ら SRBC を用いた拀体应生系て antigen sensitive VPFC はhelper $\mathrm{T}$ cell, effector $\mathrm{T}$ cell または之の前駆細胞の いうれれも属しない細胞である種の Suppressor T cell 
はないかと報告した。また Senik ら はマはウスの secondary MLC Kて VPFC $と$ cytotoxic $T$ cell $D$ 相関を認めている。 (MLCは mixed lymphocyte culture の略). 一方 Inkeles ${ }^{17)}$ は人間の系にて 細胞性免疫能の 一示標として VPA 老使用し，浇化に上りVPFC 加低 下することを述べている．Bloom ${ }^{18)}$ は悪性腫湯患者に て Con A 活性化 Tリンパ球の定量を行いその低下を 認めているが，臨像の詳細については不明である（表 11 参照)、現在までのVPA 老用いた研究を表 12 に示 t).

\section{表 11}

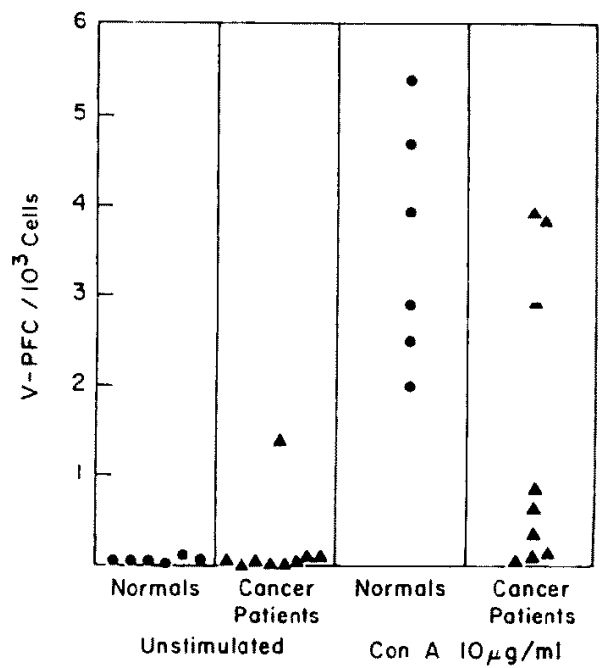

注) Bloom 5

\section{表 12}

\begin{tabular}{|c|c|c|}
\hline & VSV sensitive cells & \\
\hline 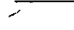 & & \\
\hline Human & $\begin{array}{l}\text { PFD reactive cells } \\
\text { Mitogen activate cells }\end{array}$ & $\begin{array}{l}\text { Jimenez et, al, } \\
\text { Bloon et, al, }\end{array}$ \\
\hline Mouse & $\begin{array}{l}\text { GVH reactive } T \text { cells } \\
I_{z} \text { reactive } T \text { ceils } \\
\text { cytotoxic T Iymphneytes } \\
\text { (precursors })\end{array}$ & $\begin{array}{l}\text { romano et,al, } \\
\text { Kano et, al, } \\
\text { senik et, al, }\end{array}$ \\
\hline & $\begin{array}{l}\text { Immature } T \text { sub set } \\
\text { OTH effector supressor }\end{array}$ & $\begin{array}{l}\text { Minato et, al, } \\
\text { Minato et, al, }\end{array}$ \\
\hline
\end{tabular}

注）VPA を用いた研究

以上が VPAを用いた研究の大要の䋓介であるが，耳

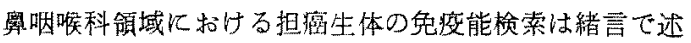

ヘたごとく，その多くが癌に非特暴的な細胞性免疫能椧

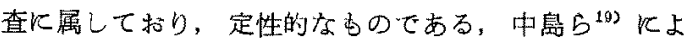
る補体と迤延型過敏症の相関儿上る免洨能の判定の派告 もあるが，これも定量的なものではない，また，田端ら

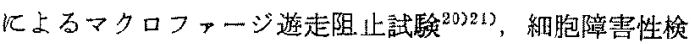
查 ${ }^{22) 233}$ の称介屯あるが，現在，結論はまだ得られていな w.

われわれが報告したVPA による Con A 活性化 T リンパ球の定量的観察では担癌生体と正常者群, その他 の疾患で著明な差学認めたが，これが Con A の活性化 作用の美に上るものではないかという疑問が生じるが， 例数が少く結諭を下すことはできないが，上記三群に括 いて著明な mitotic responsesの相異は認めていない。一

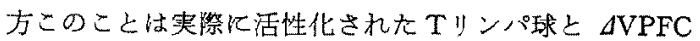

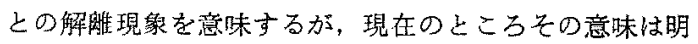
らかでない。な挸在症例を增中しつつあるが糹後に

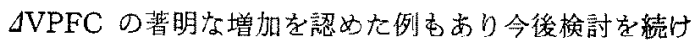
たい.

われわれは，以上のような結果より，担癌生体て打け るCon A 活性北 VPFC の著明な低下は 1) ウィル 大感受性 $T$ cell subset の消失. または，2）担癌生体 リンパ球が特異的にウィルス抵机性を獲得した。などが 考えられる.しかしながら VPAに䦎しては今後次の点 を明らかにしなければならなはと考える、1）VPFCが いかなる $\mathrm{T}$ cell subset 屈するものかの検討とその紐 胞機能の解明. 2) Con A などより誘導されるであ ろう immune Interferon など lymphokine の影響の同 定. 3）術前術後を始めとして全臨床経過をリンパ球幼 若化反応，遅延型皮過敏症などの他の細胞性免疫能检查 と平行して観察して比较検討すること.

\section{結 語}

頭钼部領域の担癌生体24例について VPA によるCon A 活性化 Tリンパ球の定量化学武み正常群，その他の 疾患群比比校して著期な低值をみた。この低值は，覀性

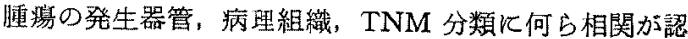
められなかった：このことより VPA は担癌生体の免疫 動態を知るうえで極めて有用であることを觀認した。

\section{言支 献}

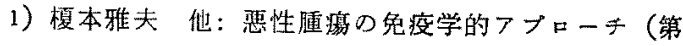

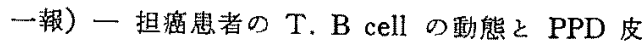

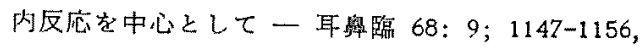
1975. 


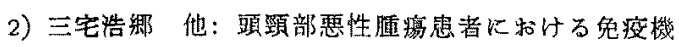

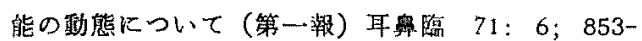
864, 1978.

3) $R J$ Eastham; T-cell Rosette Test in Squamous Cell Carcinoma of the Head and Neck. Arch Otolaryngol 102: 171-175, 1976.

4）松并和夫他：悬性腫痛の免疫学的フブローチ（符 三㪕）一担癌患者の PPD 皮内区応上 DNCB 皮 内反応について - 耳鬼臨 69: 3；307-311，1976.

5）朝合光司地：皮虔反応からみた頭项部悪性腫痬の 兔疫寮法。猃療々新薬 $15 ： 12 ; 41-46 ， 1978$.

6）滰元 街 他: 全血微量法によるりンパ球幼若化反 応，耳奥臨，71：11；1429-1436，1978.

7）菊池浩吉 他：がんと免疫，綜合臨床，26：12； 2874-2882, 1977 .

8) Bloom $B R$ : Evaluation of in Vitro Methods for Assaying Tumor Immunity. Bloom B R and David J R (editors) Academic Press, Inc New York 27-65 1976.

9) Bloom $B R$, Jimenez $L$ and Marcus $P$ I: A Plaque Assay for enumurating antigen-sensitive cells in delayed-type hypersensitivity. J. Exp. Med. 132: 16-28, 1970.

10) Jimenez $L$, Bloom $B R, M R$ Blume and $H F$ Oettgen: On the Number and Nature of AntigenSensitive Lymphocytes in the Blood of Delayed Hypersensitive Human Donors. J. Exp. Med. 133: 740-751, 1971.

11) Edelman $R$ and Wheelock $E F$ : Vesicular Stomatitis replications in human leucocyte cultures, enhancement by phytohemagglutinin. Science, 154: 1053, 1966.

12) Bloom BR: Studies on the Interactions between Viruses and Lymphocytes; Symposia on Quantitative Biology, Origins of Lymphocyte Diversity. 41: 73-82, 1977 .

13) Kano $S$ and Bloom $B R$ : Studies of the mixed Lymphocyte Reaction by the Virus Plaque Assay. Celullar Immunology. 20: 229-240, 1975.

14) Kano $S$ and Bloom $B$ R: Blocking of MLC Stimulation by anti-Ia Sera, Stimulating Studies with the Virus Plaque Assay. J. Immunology. 117: 242-245, 1976.
15) Minato $N$ and Katsura $Y$ : Virus-Replicating $T$ cells in the Immune Response of Mice. 1, Virus Plaque Assay of the Lymphocytes Reaction to sheep Erythorocytes, J. Exp. Med. 390-404, 1977.

16) Senic $A$ and Bloom $B R$ : Differentiation of Memory $T$ cells Virus Plaque-Forming Cells and Cytotoxic T Lymphocytes, J. Exp. Med. 146: $11-20,1977$

17) Inckeless $B$, etc.: Immunological Studies of Aging. J. Exp. Med. 145: 1176-1186, 1977.

18) Sutclitte $S A$ Kadish, Storen $A G$ and Bloom $B R$ : Application of the Virus Plaque Assay to the Study of Human Lymphocytes. In Vitro Methods in cell Mediation and Tumor Immunity, Bloom B R and David J R (editors), Academic Press New York. 319-341, 1976.

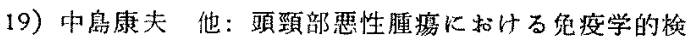
誎一「ッ反它と補体に上る 6 期分類」を中心とし

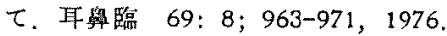

20）北庄司㒀裕 他：悪性腫疼の免疫学的アプローチ (第 2 報) - Macrophage Migration Inhibition

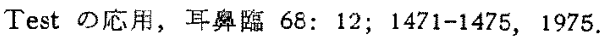

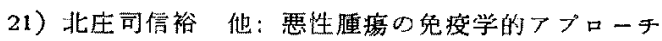
（第 5 報）一 MIT の臨床的意義に閔する知見：耳 奥臨 69: 8; 997-1000, 1976.

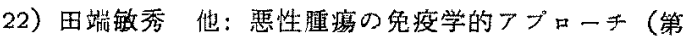
7 報）培細胞を Targetとした担滵腎者りンパ

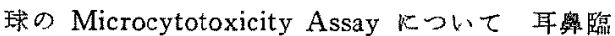
70: 4; 283-290, 1977.

23）田端敏秀 他：覀性腫痔の免疫学的フブローキ（第

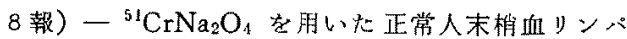
球の Cytotoxicity Assay 耳奥臨 71: 11; 1297$1402,1978$.

稿を終るにあたり，御指樂を睗わった京大胸部結核玵

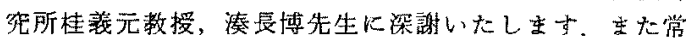
にあたたかく御教示睗わった本学微生物学岸田網太郎数 授に心上り蛒礼申乙上げます。な标，本稿の要旨は第34

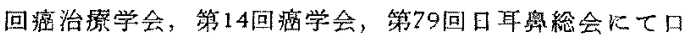
速した。

（原稿受付沼和54３.22日）

別刷請求先 $\overline{6002}$ 京都市上京区河原町通広小路上る 捤接町 465

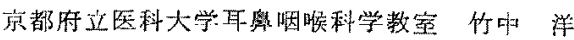

